Original article

\title{
Genome size in Calomys laucha and Calomys musculinus (Rodentia, Cricetidae)
}

\author{
MA Ciccioli, L Poggio* \\ Facultad de Ciencias Exactas y Naturales, Departamento de Ciencias Biológicas, \\ Centro de Investigaciones Genéticas (UNLP-CONICET-CIC), CC4, Llavallol, \\ 1824 Buenos Aires, Argentina
}

(Received 12 April 1991; accepted 28 December 1992)

Summary - The DNA content of 2 related species, Calomys laucha Thomas (C 1) $(2 n=64$, fundamental number $=74)$ and Calomys musculinus Fisher $(\mathrm{C} \mathrm{m})(2 n=38$, fundamental number $=62$ ) was studied using Feulgen microdensitometry using Mus domesticus as a control. Amounts of (haploid) DNA in the 2 species were significantly different (Cl: 6.940 $\mathrm{pg} ; \mathrm{Cm}: 6.202 \mathrm{pg} ; P<0.05)$. The results were analyzed in relation to: the total diploid karyotype length measured from synaptonemal complexes with a light microscope $(\mathrm{Cl}$ : $735.55 \mu \mathrm{m} ; \mathrm{Cm}: 446.30 \mu \mathrm{m} ; P<0.0001)$ and from mitotic metaphase chromosomes (Cl: $222.074 \mu \mathrm{m} ; \mathrm{Cm}: 102.651 \mu \mathrm{m} ; P<0.0001)$, the metacentric-submetacentric autosome number $(\mathrm{Cl}: 8 ; \mathrm{Cm}: 22)$ and the area of chromocenters showing positive staining with C-banding technique (heterochromatin) (Cl: 100\%; Cm: 99.66\%).

The DNA amount in pg per unit length of karyotype (measured from synaptonemal complexes) is higher in Calomys musculinus $(0.028 \mathrm{pg} / \mu \mathrm{m})$ than in Calomys laucha $(0.019 \mathrm{pg} / \mu \mathrm{m})$. This indicates that there is not a constant amount of DNA associated with a given length of karyotype, which suggests that the difference between the 2 species may involve differential packing of DNA. This could be due to: genic differences; differential interactions between genes and the cellular environment; and/or alteration of gene expression following the formation of new linkage groups due to chromosomal rearrangements.

Calomys musculinus / Calomys laucha / C-value / karyotype length / synaptonemal complex

Résumé - Taille du génome chez Calomys laucha et Calomys musculinus (Rongeurs, Cricétidés). La teneur en $A D N$ de 2 espèces apparentées Calomys laucha Thomas ( $\mathrm{Cl}$ $2 n=64$, nombre fondamental $=74)$ et Calomys musculinus Fisher $(\mathrm{Cm} 2 n=38$, nombre fondamental $=62)$ a été étudiée par microdensitométrie avec Feulgen, en utilisant Mus

* Correspondence and reprints 
domesticus comme témoin. Les teneurs en ADN (haploïde) des 2 espèces ont montré des différences significatives $(\mathrm{Cl}=6,940 \mathrm{pg} ; \mathrm{Cm}=6,202 \mathrm{pg} ; \mathrm{P}<0,05)$. Les résultats ont été analysés en relation avec : la longueur totale (diploïde) du caryotype, mesurée en microscopie optique à partir des complexes synaptonémiques $(\mathrm{Cl}: 735,55 \mu \mathrm{m} ; \mathrm{Cm}$ : $446,30 \mu \mathrm{m} ; \mathrm{P}<0,0001)$ et à partir des chromosomes en métaphase $(\mathrm{Cl}: 222,07 \mu \mathrm{m} ; \mathrm{Cm}$ $: 102,65 \mu \mathrm{m} ; P<0,0001$ ), le nombre des autosomes métacentriques-submétacentriques $(\mathrm{Cl}: 8 ; \mathrm{Cm}: 22)$ et la surface des chromocentres montrant une coloration positive avec la technique de bande $C$ (hétérochromatine) ( $\mathrm{Cl}: 100 \%$; $\mathrm{Cm}: 99,66 \%$ ).

La quantité d'ADN exprimée en picogrammes par unité de longueur du caryotype (mesurée sur les complexes synaptonémiques) est plus élevée chez Calomys musculinus $(0,028 \mathrm{pg} / \mu \mathrm{m})$ que chez Calomys laucha $(0,019 \mathrm{pg} / \mu \mathrm{m})$. Cela indique et suggère que la différence entre ces 2 espèces pourrait impliquer un empaquetage différent de l'ADN. Cela pourrait être dî à des différences géniques, des interactions différentielles entre les gènes et le milieu cellulaire, et/ou des expressions de gènes modifiées suite à la formation de nouveaux groupes de liaison par suite de remaniements chromosomiques.

Calomys musculinus / Calomys laucha / valeur-C / longueur du caryotype / complexe synaptonémique

\section{INTRODUCTION}

The genus Calomys (Phyllotinae) has not been completely studied and the taxonomical and phylogenetical relationships between its species are still somewhat uncertain (Cabrera, 1961; Hershkovitz, 1962; Reig, 1984). The ancestral karyotype of the Phyllotinae is $2 n=70$, fundamental number $(\mathrm{NF})=68$, most of the chromosomes being acrocentric (Pearson and Patton 1976). The present species of Calomys exhibit a range of chromosome numbers from $2 n=64(\mathrm{NF}=68)$ to $2 n=36$ (NF $=68$ ) (Hurtado de Catalfo and Waimberg, 1974; Lisanti et al, 1976; Pearson and Patton, 1976; Gardenal et al, 1977; Forcone et al, 1980).

$C$ laucha and $C$ musculinus are 2 cricetid rodents, significant from a health point of view because they are vectors of the Junin virus which causes the Argentine haemorrhagic fever (Gardenal et al, 1977). These 2 species are synmorphic and sympatric species (Hershkovitz, 1962; Massoia et al, 1968; Gardenal et al, 1977; Reig, 1984) and it is very difficult to differentiate them in the field. However, they present very distinctive karyotypes since $C$ laucha has $2 n=64(\mathrm{NF}=74)$ and $C$ musculinus has $2 n=38(\mathrm{NF}=62)$ chromosomes (Pearson and Patton, 1976; Gardenal et al, 1977; Ciccioli, 1988, 1991).

The main mechanism involved in the chromosomal evolution of rodents is that of Robertsonian fusions (White, 1973; Capanna et al, 1976; Gropp and Winking, 1981). Although this mechanism would be the most parsimonious explanation in Calomys (Pearson and Patton 1976), other types of rearrangements are needed to explain the karyotype change between the 2 species, such as superimposed pericentric inversions (Forcone et al, 1980; Ciccioli, 1991). In C musculinus a double centromeric region was observed by electron microscopy (EM) on synaptonemal complexes (SC) (Ciccioli, 1991) in ca 12 of a total of 19 bivalents (Ciccioli and Rahn, 1984; Ciccioli, in preparation). Moens (1978) observed in Neopodismopsis that each of 2 submetacentric Robertsonian fusion have "a centric knob which is 
double in size and structure". In house mice, Redi et al (1986) said that "it has been inferred (Gropp and Winking, 1981) that $\mathrm{Rb}$ translocation occurs with loss of the 2 shortest arms of the acrocentrics involved in translocation, probably followed by functional inactivation of a centromere (Hsu et al, 1975)". This mechanism does not necessarily imply a quantitative variation in total DNA content since in Mus poschiavinus there is apparently little or no quantitative change in genome size (C-value) (Manfredi-Romanini et al, 1971; Comings and Avelino, 1972; Redi et al, 1986).

The difference in genome size between $C$ laucha and $C$ musculinus are studied by Feulgen microdensitometry in the present paper. The aim of this work is focused on the relationships between DNA content and the total karyotype length (TKL) (measured on synaptonemal complexes (SC) and on metaphase mitotic chromosomes (MMC)), as well as other nucleotypical parameters (Bennett, 1987; Grant, 1987). Moreover, additional information on genome size will be discussed.

\section{MATERIALS AND METHODS}

Six male individuals from Laguna Larga (Province of Córdoba, Argentina) of each species ( $C$ laucha and $C$ musculinus) and one individual of Mus domesticus (Province of Buenos Aires) were studied.

\section{DNA content measurements (Feulgen microdensitometry)}

Slides were prepared by dispersion and air-drying from specimens which had not been pretreated. In $C$ musculinus, slides of meiosis (from testis) and mitosis (from bone marrow) were made. In C laucha and $M$ domesticus, the same procedure was followed using only bone marrow.

Hydrolysis was carried out with $5 \mathrm{~N} \mathrm{HCl}$ at $20^{\circ} \mathrm{C}$. Different times of hydrolysis were tested $(10,20,30,35,40,50$ and $60 \mathrm{~min})$ and hydrolysis curves were determined. After hydrolysis, the slides were rinsed 3 times with distilled water for $10 \mathrm{~min}$ each.

Staining was carried out with Feulgen stain at $\mathrm{pH} 2.2$ for $2 \mathrm{~h}$. Slides were rinsed 3 times in $\mathrm{SO}_{2}$-water for $10 \mathrm{~min}$ each time, and then in distilled water $(10 \mathrm{~min})$.

The slides were air-dried in the dark and mounted in Euparal.

In slides of testes, measurements were made on spermatids and sperm, and lymphocytes were measured in slides of bone marrow. The values obtained were expressed in arbitrary units (AU), or in absolute units (pg of DNA) using Mus domesticus as a control, the DNA content of which is known by chemical methods $(\mathrm{C}=7 \mathrm{pg}$ (Lewin, 1980)).

To ensure the accuracy of the measurements in the case of $C$ musculinus, the relationships between DNA content measurements at prophase (4C) and telophase (2C) was checked to correspond to the ratio 2:1 in mitotic lymphocytes (AU 35.23 and $A U 16.85$ respectively) and 4:1 in prophase I (4C) and telophase II (1C) of meiotic cells (AU 36.24; AU 9.63).

The amount of Feulgen staining per nucleus was measured at a wavelength of $570 \mathrm{~nm}$ using the scanning method in a Zeiss Cytoscan. In both species, the readings were made in the same individuals in which synaptonemal complexes were 
measured. The differences in DNA content between species were tested with a Student $t$-test.

\section{Synaptonemal complexes using light microscopy (LM)}

Synaptonemal complexes (SC) were studied using the method described by Solari (1983) for electron microscopy, adapted by modifying the stain to $50 \%$ (W/V) of $\mathrm{AgNO}_{3}$ in distilled water. Two or 3 drops of silver nitrate solution were placed on previously air-dried slides. Floating coverslips were put on the slides, which were incubated in a moist chamber at $60^{\circ} \mathrm{C}$ for $3-5 \mathrm{~h}$. Staining was monitored under a phase contrast objective until yellowish pachytene muclei were seen with dark brown SCs. The process was stopped by washing with distilled water. Slides were air-dried and mounted in DEPEX.

The total karyotype length (TKL) was measured from optical micro-photographs. Five mid-pachytene nuclei were measured for each species. The length of the SC was measured 3 times and an average value was determined for each autosomic bivalent. The same procedure was followed for the lateral elements of the $\mathrm{X}$ and $\mathrm{Y}$ chromosomes. The TKL (SC) was calculated by doubling the average value for each autosome and adding that of the lateral elements of the sexual pair. All measurements were carried out using a Mini-Mop (Kontron) Image Analyzer. The differences in TKL length measured on SC (LM) between species were tested with a Student $t$-test.

\section{Conventional karyotypes}

The animals were injected with a yeast solution on 2 successive days to increase the mitotic index (Lee and Elder, 1980). On the third day they were injected with a colchicine solution $(0.0025 \%)$. Two hours later, they were etherized and the bone marrow extracted according to routine techniques (Evans et al, 1964). The preparations were made by dispersion and air-drying.

The karyotypes were described according to the nomenclature proposed by Levan et al (1964) ( $\mathrm{m}, \mathrm{sm}$ and st: chromosomes with centromeres in the median, submedian and subterminal region, respectively). The average centromeric indexes, short arms, long arms, total chromosome length and chromatid width were measured and calculated in 3 cells. The total chromosome volume (TCV) was obtained by considering each chromosome as 2 cylinders. The formula used was ( $\left.\widetilde{\mathrm{II}} \times r^{2} \times h\right) \times 2(r$ $=$ half the chromatid width; $h=$ chromosome length). Measurements were carried out using a Mini-Mop (Kontron) Image Analyzer. The differences in TKL length on mitotic metaphase chromosomes between species were tested with an approximate Student $t$-test (Games and Howell, 1976), on the assumption of heterogeneity of variances (Sokal and Rohlf, 1981).

\section{C-banding}

The C-banding technique was performed on conventionally prepared slides as follows: a) $60 \%$ acetic acid for $30 \mathrm{~min}$; b) $0.2 \mathrm{~N} \mathrm{HCl}$ for $1 \mathrm{~h}$; c) solution $(\mathrm{OH})_{2}$ $\mathrm{Ba}$ sat in distilled water, $12-15 \mathrm{~min}$ at $20^{\circ} \mathrm{C}$; d) $2 \times \mathrm{SSC}$ for $45-60 \mathrm{~min}$ at $60^{\circ} \mathrm{C}$; 
e) $2 \%$ Giemsa in buffer phosphate ph 6.8 for 10-12 min. The heterochromatin area per interphase nucleus was obtained by measuring the area of each $\mathrm{C}$ positive chromocenter within each nucleus. The total area of chromocenters from 10 nuclei was averaged in each species. The values obtained are expressed in table I where $C$ laucha is given the $100 \%$ value. The measurements were carried out using a Mini-Mop (Kontron) Image Analyzer, working with photomicrographs with similar exposure time, development procedure and enlargement in both species.

\section{Table I.}

\begin{tabular}{|c|c|c|}
\hline Species & C laucha & C musculinus \\
\hline $2 n$ & 64 & 38 \\
\hline NF & 74 & 62 \\
\hline$m$ - sm autosome number & 8 & 22 \\
\hline $\begin{array}{l}\text { DNA content } \\
\mathrm{C}(\mathrm{pg}) ; \overline{\mathrm{X}} \pm \mathrm{SE} \\
\text { Sample size } \\
t \text {-test value, significance }\end{array}$ & $\begin{array}{l}6.940 \pm 0.21 \\
18 \quad t=2 .\end{array}$ & $\begin{array}{l}6.202 \pm 0.20 \\
30 \\
0.05\end{array}$ \\
\hline $\begin{array}{l}\text { TKL }(\mu \mathrm{m})(\mathrm{SC}) \\
\bar{X} \pm \mathrm{SE} \\
\text { Sample size } \\
t \text {-test value, significance }\end{array}$ & $\begin{array}{r}735.55 \pm 32.50 \\
5 \quad t=7.8\end{array}$ & $\begin{array}{l}446.30 \pm 17.02 \\
5 \\
.0001^{5}\end{array}$ \\
\hline $\begin{array}{l}\mathrm{TKL}(\mu \mathrm{m})(\mathrm{MMC}) \\
\overline{\mathrm{X}} \pm \mathrm{SE} \\
\text { Sample size } \\
t \text {-test value, significance }\end{array}$ & $\begin{array}{r}222.074 \pm 0.923 \\
5 \\
t=37.2\end{array}$ & $\begin{array}{l}102.651 \\
5 \\
0.0001\end{array}$ \\
\hline DNA $(2 \mathrm{C} ; \mathrm{pg}) / \mathrm{TKL} \mathrm{SC}(\mu \mathrm{m})$ & 0.019 & 0.028 \\
\hline NA (\%) & 100 & 54.43 \\
\hline $\mathrm{HA}(\%)$ & 100 & 99.66 \\
\hline
\end{tabular}

$2 n$ : diploid number. NF: fundamental number. TKL: total karyotype length. SC: synaptonemal complex. MMC: mitotic metaphase chromosome. TCV: total chromosomal volume. NA: nuclear area. HA: heterochromatin $\mathrm{C}(+)$ area. $\mathrm{m}$ : chromosomes with centromere in the median region. sm: chromosomes with centromeres in the submedian region. $\mathrm{SE}$ : standard error.

\section{RESULTS AND DISCUSSION}

The karyotype of $C$ laucha $(2 n=64 ; \mathrm{NF}=74)$ comprised $8 \mathrm{~m}$-sm (pairs 1-4) +54 st-t $+\mathrm{X}(\mathrm{m}) \mathrm{Y}(\mathrm{m})($ fig $1 \mathrm{~A})$. C musculinus $(2 n=38 ; \mathrm{NF}=62)$ had a karyotype with $22 \mathrm{~m}$-sm (pairs 1 to 11$)+14 \mathrm{st}+\mathrm{X}(\mathrm{m}) \mathrm{Y}(\mathrm{m})$ (fig $1 \mathrm{~B})$.

The species were measured at their optimum hydrolysis time, ie: Claucha: lymphocytes $30 \mathrm{~min}$; $C$ musculinus: spermatids $35 \mathrm{~min}$, sperm $40 \mathrm{~min}$ and lymphocytes 35 min (fig 2). The differences related to hydrolysis time and DNA content observed 


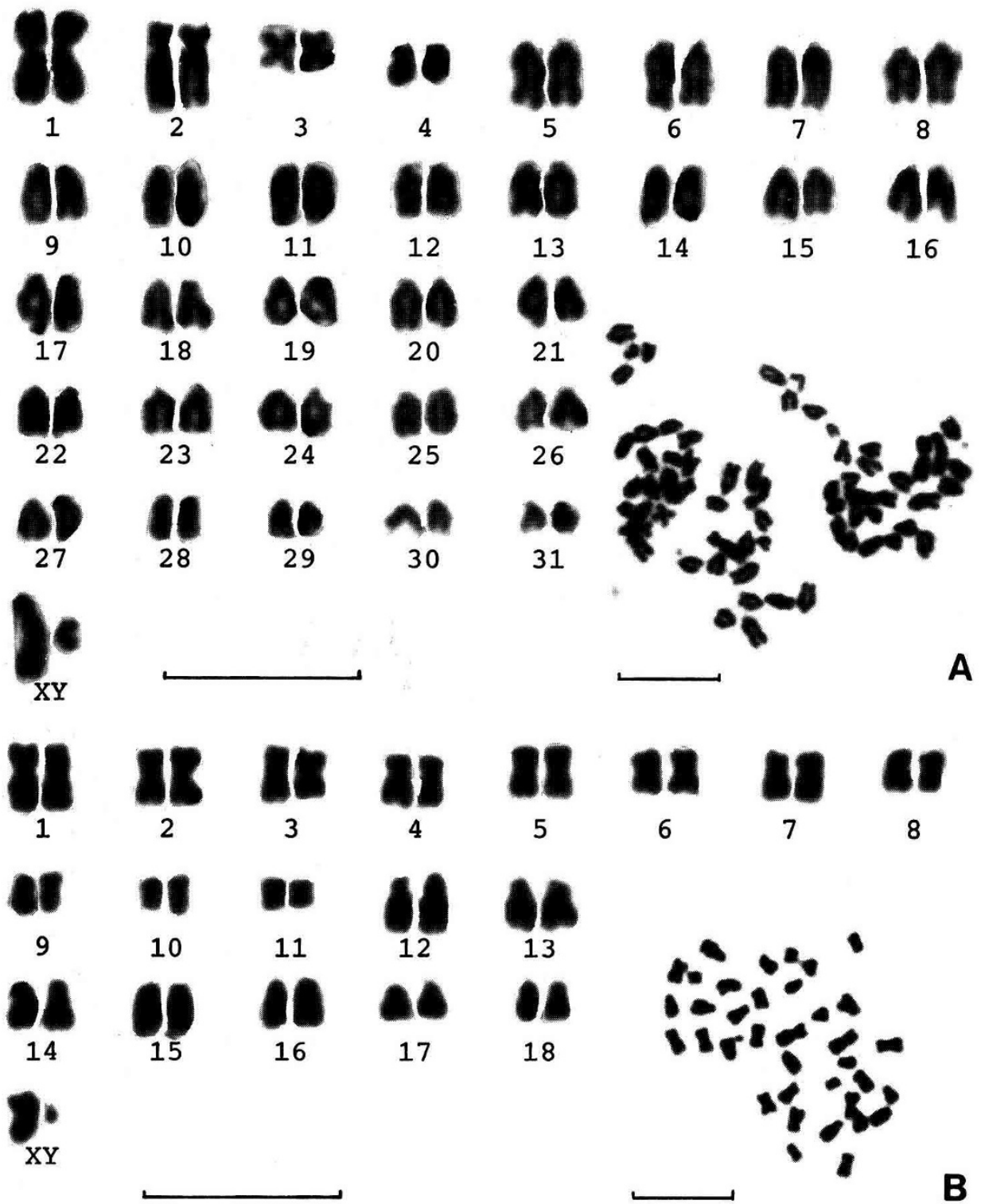

Fig 1. Mitotic metapl ase karyotypes. (A) $C$ laucha; (B) $C$ musculinus. The scale represents $10 \mu \mathrm{m}$.

between spermatids and sperm in $C$ musculinus (arbitrary units) are remarkable and may be explained by the higher degree of chromatin condensation in sperm. This could be due to the chromatin condensation gradient which could have reduced the possibility of eliminating the depurinated DNA fragments during acid 

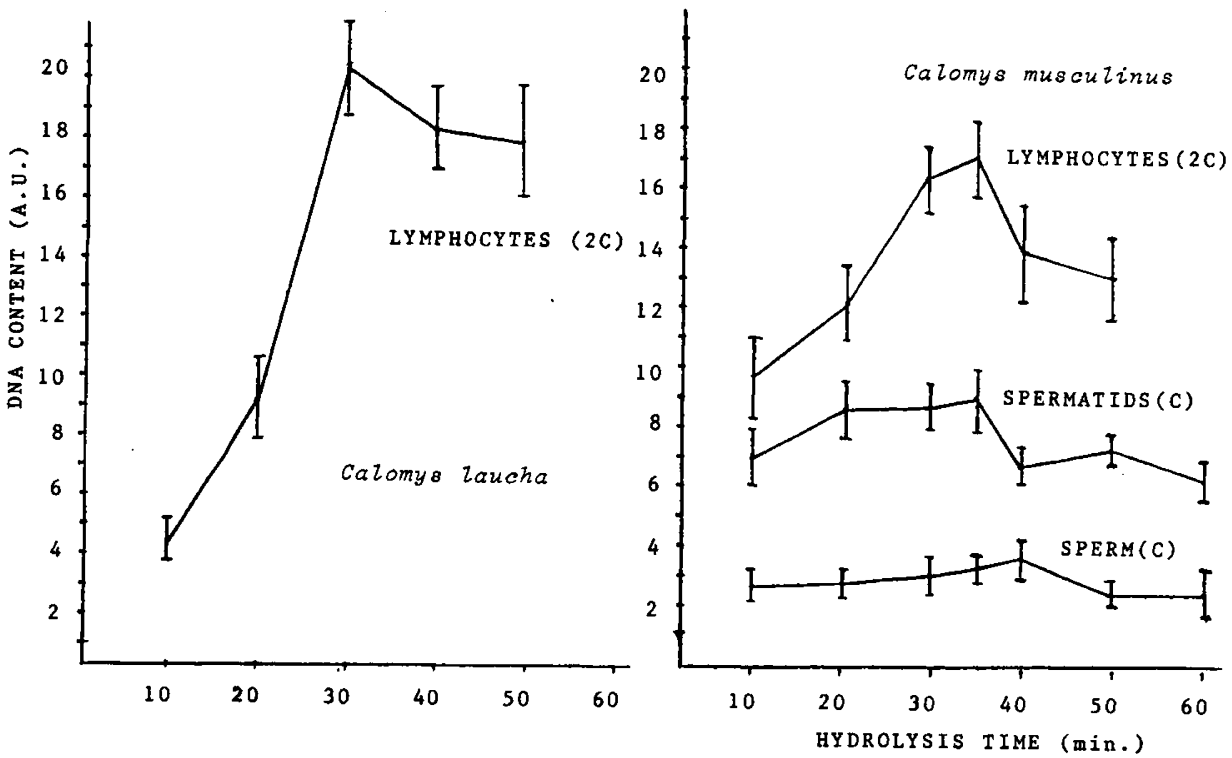

Fig 2. Hydrolysis curves in Calomys laucha (lymphocytes $2 \mathrm{C}$ ) and Calomys musculinus (lymphocytes 2C, spermatids C, sperm C).

hydrolysis (Holmquist, 1979). This could also explain the small differences found in the optimum hydrolysis time between both species.

Table I shows the DNA content expressed in absolute values (pg) in both species. The differences in C-values between $C$ musculinus and $C$ laucha were significant: $t$ $(46)=2.331, P=0.0226$ ) (Bartlett test for homogeneity of variances, $\chi^{2}=1.8877$, $\mathrm{DF}=1, P=0.1656)$. The DNA content and TKL presented a positive relationship with chromosome number (table I).

Synaptonemal complexes in mid-pachytene nuclei of $C$ laucha and $C$ musculinus prepared for the light microscope (LM) are shown in figure 3 . The difference in the total karyotype length (TKL) between $C$ laucha and $C$ musculinus, as measured from SCs, was highly significant: $t(8)=7.88, P=0.000076$ (Bartlett test for homogeneity of variances $\chi^{2}=1.3288, \mathrm{DF}=1, P=0.2475$ ) (table I).

Comparisons of TKL based on SC measurement can be inaccurate, because of at least 2 possible sources of error (Anderson et al, 1985). One is the biological variability among different substages of pachytene. This variation must be discarded in the present study because only nuclei in mid-pachytene were chosen. The other is the physical stretching of SCs during dispersion in the hypotonic hypophase. In the present work, those nuclei which showed evidence of stretching were discarded. Still another source of error, when different species are compared, involves the quantity of heterochromatin. Compared to euchromatin, heterochromatin is, on average, 2 to 5 times under-represented in the length of pachytene chromosomes, due to its different condensation state in pachytene and metaphase (Stack 1984).

In both species of Calomys C-banding revealed that the amount of heterochromatin measured in interphasic $\mathrm{C}+$ chromocenters is similar (Calomys laucha $=$ 

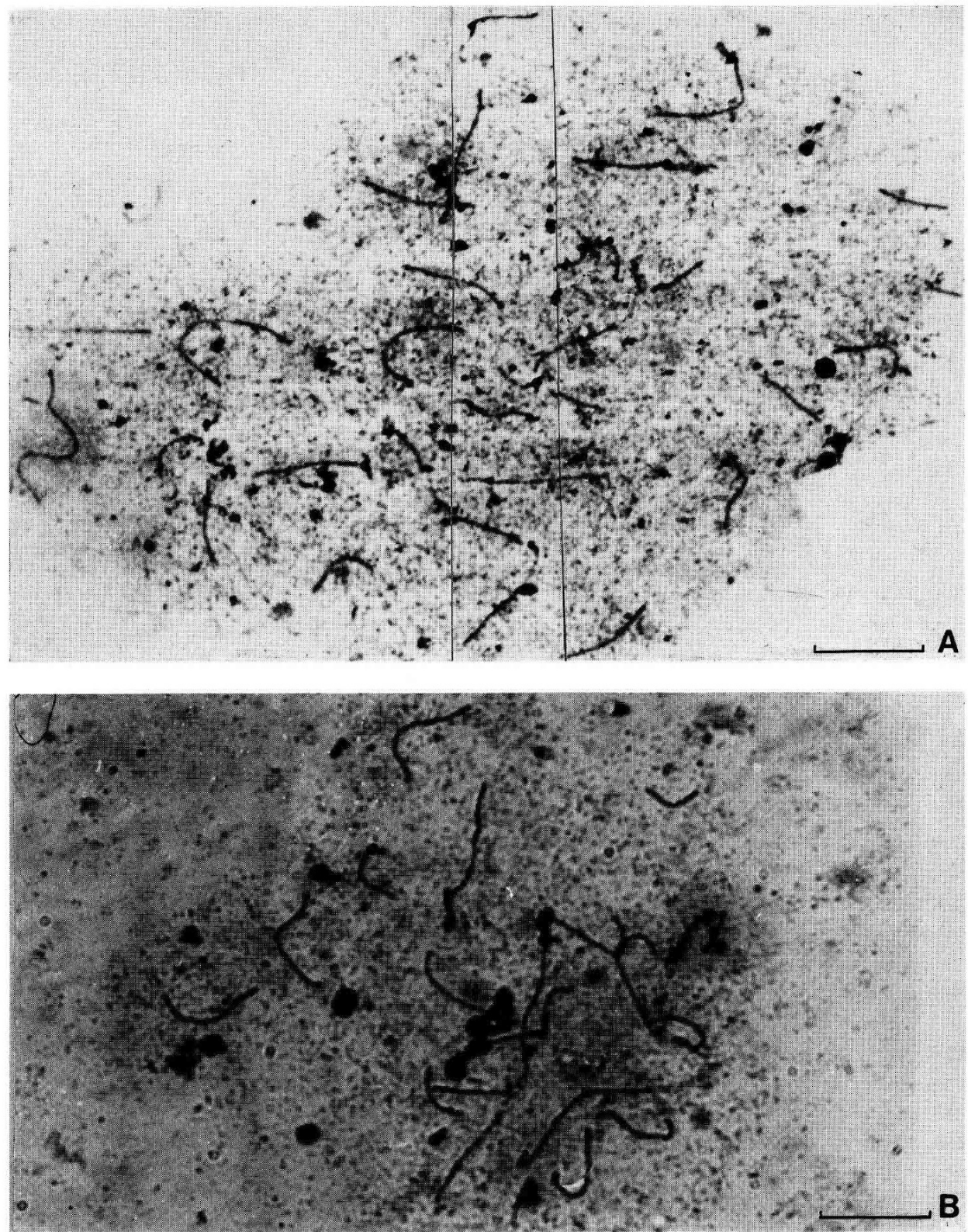

Fig 3. Synaptonemal complexes (SC) under LM. (A) C laucha $(2 n=64)$. (B) $C$ musculinus $(2 n=38)$. The scale represents $10 \mu \mathrm{m}$. 
$100 \% ;$ Calomys musculinus $=99.66 \%$ ) (table I). Thus, the effect of differences in the quantity of heterochromatin on SC length between the species is negligible. The heterochromatin was expressed in absolute value and not in relation to the nuclear area of lymphocytes since both species differ significantly in this parameter $(\mathrm{Cl}=$ $100 \%, \mathrm{Cm}=54.43 \%$ ). This difference follows the same pattern of variation as the TKL. Such differences in TKL measured on mitotic metaphase chromosomes are larger than those found on SCs (table I). Differences in the TKL between $C$ laucha and $C$ musculinus measured on mitotic metaphase chromosomes was highly significant: $t^{\prime}(5)=37.27, \mathrm{DF}=4.72 \approx 5, P=0.00002$ (Bartlett test for heterogeneity of variances $\left.\chi^{2}=4.2227, \mathrm{DF}=1, P=0.0375\right)$. The use of mitotic arresting agents such as colchicine may also lead to errors because they produce dose-related variation in chromatin contraction. In the present work, however, this should not be an important source of error since the same dose concentration and exposure were used during the experiments.

Variations in TKL for both sets of data (SC, MMC) show the same pattern of variation which suggests that the highly significant differences between the species are not an artefact but have a high genetic component.

Anderson et al (1985) showed that there is a strong correlation between TKL (SC length) and genome size in higher plants, indicating that a constant amount of DNA is associated with a given length of SC, at least when averaged over the whole genome. Whereas this statement is convincing when species within the same genus are compared (eg Allium) indicating that they have a similar chromosomal organization, the range in variation in DNA content per unit of SC length is much larger when other genera are included (eg Solanum sparsipilum). C laucha and $C$ musculinus also present a positive relationships between DNA content and SC length. However, in spite of being closely related species, the TKL of $C$ musculinus is $39.3 \%$ (SC) and $54.3 \%(\mathrm{MMC}$ ) lower than that of $C$ laucha, while the difference in DNA content is only $10.6 \%$. It may be worth mentioning that the difference of chromosome volume in mitotic chromosomes - though not accurately measured because chromosome width was near the resolution limit of our Mini-Mop Image Analyzer - is of the same order $\left(6.5 \%, \mathrm{Cl}=318 \mu \mathrm{m}^{3} ; \mathrm{Cm}=297 \mu \mathrm{m}^{3}\right)$ as the difference in DNA content.

Consequently, the amount of DNA per unit length of karyotype is much higher in $C$ musculinus than in Claucha (Table I), and in these species a given length of karyotype does not contain a constant amount of DNA. This may be explained by the existence of different interactions between the nucleotypical parameters such as SC length and DNA amount. This could indicate that differential packing of DNA is an important difference between the species, due to, among other reasons: a) genetic differences, b) differential interaction between genes and the cellular environment, and/or c) alteration of gene expression due to the formation of new linkage groups following chromosome rearrangements. The TKL variation pattern is similar to that of the nuclear area (table I). Cavalier-Smith (1983) states that "the nuclear volume is jointly determined by: 1) nuclear DNA content; 2) the degree of folding of the DNA and its pattern of attachment to the nuclear envelope". In the present work, the main factor responsible for the significant differences in nuclear area and TKL could be the degree of folding as suggested by the differences found in hydrolysis times between the two species, and the pattern of attachment to the 
nuclear envelope, probably due to the decrease in telomere number in Calomys musculinus. These interactions could be considered part of the genome ecology of the genus (Bennett 1987).

\section{ACKNOWLEDGMENTS}

The authors are especially indebted to PE Brandham (Jodrell Laboratory, RBG, Kew, UK), CA Naranjo for critically reading the manuscript and for their valuable suggestions, to the laboratory of virology (Depto Química Biológica, FCE y Nat, UBA) for the specimens of $C$ musculinus, and to F Kravetz for the specimens of $C$ laucha and Mus domesticus. They also thank $\mathrm{R}$ Cabrini for the use of a microdensitometer belonging to the CNEA and the statistician B Gonzalez for a careful revision of tests and data. This work was supported by a CONICET grant.

\section{REFERENCES}

Anderson LK, Stack SM, Fox MH, Chuanshan Z (1985) The relationship between genome size and synaptonemal complex length in higher plants. Exp Cell Res 156, 367-378

Bennett MD (1987) Variation in genomic form in plants and its ecological implications. New Phytol 106 (suppl), 177-200

Cabrera A (1961) Catálogo de los mamíferos de América del Sur. Rev Mus Arg Cien Nat Bernardino Rivadavia, Cien Zool 4(22), 309-732

Capanna E, Gropp A, Winking H, Noack G, Civitelli MV (1976) Robertsonian metacentrics in mouse. Chromosoma 58, 341-353

Cavalier-Smith $\mathrm{T}$ (1983) Cell volume and genome size. In: Kew Chromosome Conference II (Brandham PE, Bennett MD, eds) Royal Bot Gardens, Kew, London Ciccioli MA, Rahn I (1984) Estudios meióticos en Calomys musculinus (Rodentia, Cricetidae). In: XV Congr Arg Genet Corrientes, 25, Soc Arg Genética Corrientes, Argentina

Ciccioli MA (1988) Cytogenetic studies in Calomys musculinus (Rodentia, Cricetidae). Cytologia 53, 7-17

Ciccioli MA (1991) Classical, C- and Cd-banding karyotypes in mitotic and meiotic chromosomes of Calomys musculinus (Rodentia, Cricetidae). Caryologia 44(2), 177186

Comings DE, Avelino E (1972) DNA loss during Robertsonian fusion studies of the tobacco mouse. Nature (Lond) New Biol 237, 199

Evans E, Breckon G, Ford C (1964) An air-drying method for meiotic preparations from mammalian testes. Cytogenetics 3, 289-294

Forcone AE, Luna MV, Kravetz FO, Lisanti JA (1980) Bandas C y G de Calomys musculinus (Rodentia, Cricetidae). Mendeliana 4, 57-65

Games PA, Howell JF (1976) Pairwise multiple comparisons procedure with unequal $N s$ and/or variances: a Montecarlo study. J Educ Stat 1, 113-125

Gardenal CN, Triay de Juarez N, Gutierrez M, Sabattini MS (1977) Contribución al conocimiento de tres especies del género Calomys (Rodentia, Cricetidae). Physis C 36 (92) 169-178 
Grant WF (1987) Genome differentiation in higher plants. In: Differentiation Patterns in Higher Plants (Urbanska KM, ed) Academic Press, New York, ch 1, 9-32

Gropp A, Winking E (1981) Robertsonian translocation: cytology, meiosis, segregation patterns and consequences of heterozygosity. Symp Zool Soc Lond 47, 141-181 Hershkovitz P (1962) Evolution of neotropical cricetine rodents (Muridae) with special reference to the phyllotine group. Fieldiana: Zool 46, 1-524

Holmquist G (1979) The mechanism of C-banding depurination and $\beta$-elimination. Chromosoma 72, 203-224

Hsu TC, Pathak S, Chen TR (1975) The possibility of latent centromeres and a proposed nomenclature system for total chromosome and whole arm translocations. Cytogenet Cell Genet 15, 41-49

Hurtado de Catalfo G, Waimberg R (1974) Citogenética de Calomys callosus callosus (Rengger 1830), (Rodentia Cricetidae). Análisi $\leqslant$ métrico del cariotipo somático. Physis C 33 (87) 215-219

Lee MR, Elder F (1980) Yeast stimulation of bone marrow mitosis for cytogenetics investigations. Cytogenet Cell Genet 26, 36-40

Levan A, Fredga K, Sandberg AA (1964) Nomenclature of centromeric position on chromosomes. Hereditas 52, 201-220

Lewin B (1980) Gene Expression 2. Eukaryotic Chromosomes. John Wiley and Sons Inc, New York, 1160

Lisanti JA, Kravetz FO, Ramirez CL (1976) Los cromosomas de Calomys callosus (Rengger) (Rodentia Cricetidae) de la Provincia de Cordoba. Physis C 35, 221-230 Manfredi-Romanini MGM, Minazza E, Capanna E (1971) DNA nuclear content in lymphocytes from Mus musculus L, and Mus poschiavinus (Fatio). Biol Zool 38, 321-326

Massoia E, Fornes A, Waimberg R, Fronza T (1968) Nuevos aportes al conocimiento de las especies bonaerenses del género Calomys Rev Inv Agrop INTA 5, 63-92

Moens PB (1978) Kinetochores of grasshoppers with Robertsonian chromosome fusions. Chromosoma 67, 41-54

Pearson . OP, Patton JL (1976) Relationships among South American phyllotine rodents based on chromosome analysis. $J$ Mammal 57, 2, 339-350

Redi CA, Garagna S, Mazzini G, Winking H (1986) Pericentromeric heterochromatin and A-T content during Robertsonian fusion in the house mouse. Chromosoma $94,31-35$

Reig OA (1984) Significado de los métodos citogenéticos para la distinción e interpretación de las especies con especial referencia a los mamiferos. In: Conf III, Congr Iberoam Zool IV. Peru, Soc Zool, Perú

Sokal RR, Rohlf FJ (1981) Biometry. WH Freeman and Co, New York

Solari AJ (1983) Recombination bars in human synaptonemal complexes spread with sodium dodecyl sulphate. Microsc Elec y Biol Cel 7(1), 1-11

Stack SM (1984) Heterochromatin, the synaptonemal complex and crossing-over. J Cell Sci 71, 159-176

White MJD (1973) Animal Cytology and Evolution. Cambridge Univ Press, Cambridge, $3 \mathrm{rd}$ edn 